\title{
SIMULTANEOUS REPAIR OF THE SKULL BASE AND THE FRONTAL LOBE DEFECT USING CAD-CAM TECHNOLOGY
}

Ivanov OV凶

Federal Siberian Research and Clinical Center of FMBA of Russia, Krasnoyarsk, Russia

Many patients with traumatic brain injury develop complications in the postoperative period. The article describes a case of revision surgery in a female patient with cerebrospinal fluid rhinorrhea following a severe car accident. During one surgery, the skull base and the frontal bone defect were repaired and a lumboperitoneal shunt was placed. The skull base was repaired using an autologous musculoaponeurotic graft. For a better cosmetic effect, the implant was designed using CADCAM technologies. The patient had a relapse of the leak in the postoperative period, which required revision surgery (multilayer reconstruction using a fibrin-thrombin sponge). The patient was followed up for 2 years, with no relapse. The desired clinical and cosmetic effects were successfully achieved.

Keywords: cranial bone defect, reconstructive surgery, CAD-CAM technology, CSF leak, fibrin glue

Acknowledgments: the authors thank Urasovsky IB, Director of Logeeks Medical Systems, and Panchencko AA, Director of Engineering, for their help in creating the customized implant.

Funding: the work was part of the State Assignment on the Cranial bone defect repair with shape memory materials.

Compliance with ethical standards: the patient gave her informed consent to participate in the study

$\varangle$ Correspondence should be addressed: Evgeniya A. Blinova

Vorovskogo, 68, korp. 1, Chelyabinsk, 454141, Russia; blinova@urcrm.ru

Received: 07.10.2021 Accepted: 25.10.2021 Published online: 08.11.2021

DOI: $10.47183 /$ mes.2021.038

\section{СИМУЛЬТАННАЯ РЕКОНСТРУКЦИЯ ОСНОВАНИЯ ЧЕРЕПА И ДЕФЕКТА ЛОБНОЙ КОСТИ С ИСПОЛЬЗОВАНИЕМ САD-САМ-ТЕХНОЛОГИЙ}

О. В. Иванов $\bowtie$

Федеральный Сибирский научно-клинический центр Федерального медико-биологического агентства, Красноярск, Россия

После черепно-мозговой травмы в послеоперационный период у пациентов нередко возникают осложнения. Представлен случай ревизионной операции по поводу назальной ликвореи после тяжелой автодорожной травмы. Пациентке в ходе одной операции провели реконструкцию основания черепа, дефекта лобной кости и люмбоперитонеальное шунтирование. Реконструкцию основания черепа выполнили мышечно-апоневротическим аутотрансплантатом, для лучшего косметического эффекта использовали имплант, изготовленный с использованием CAD-CAM-технологий. B послеоперационном периоде возник рецидив назоликвореи, потребовавший повторной многослойной пластической операции на основании черепа с использованием фибрин-тромбиновой клеевой композиции. Послеоперационное наблюдение составило более двух лет, рецидива ликвореи не отмечено, достигнут желаемый клинический и косметический результат.

Ключевые слова: дефекты костей черепа, реконструктивно-пластическая операция, CAD-CAM-технологии, назоликворея, фибрин-тромбиновый клей Благодарность: авторы признательны директору ООО «ЛОГИКС медицинские системы» И. Б. Урасовскому и техническому директору А. А. Панченко за помощь в проектировании индивидуального импланта.

Финансирование: субсидия на выполнение государственного задания ФМБА по теме «Замещение десектов костей черепа с применением материалов с памятью формы».

Соблюдение этических стандартов: пациентка подписала добровольное информированное согласие на исследование.

$\triangle$ Для корреспонденции: Олег Викторович Иванов

ул. Коломенская, д. 26, г. Красноярск, 660133, Россия; 2978395@mail.ru

Статья получена: 07.10.2021 Статья принята к печати: 25.10.2021 Опубликована онлайн: 08.11.2021

DOI: $10.47183 /$ mes.2021.038

The first description of cranioplasty dates back to 1505, when it appeared in the surgery textbook Alâ'im-i Cerrâhîn (Wonders of Surgeons) written by lbrahim ben Abdullah [1]. Later on, the Italian physician Fallopius Gabriele (1523-1562) described a method for closing cranial defects with a gold plate. A similar method was documented by Petronius in 1565. In 1668, Van Meekeren reported a case of cranioplasty with a canine bone graft performed in a Russian nobleman who had sustained a sword injury to the head [2]. In 1965, D. Simpson proposed titanium as a material for reconstructive surgery. Since then, titanium and its alloys have been widely adopted in surgical practice. Craniofacial injury poses a serious diagnostic and therapeutic challenge to modern neurotraumatology. Conventionally, such type of injury is managed in two steps. First, surgical debridement is performed: crushed fragments of the frontal bone, including the superior margin of the orbital rim, the roof of the orbit and frontal sinus tables, are removed while trying to preserve as much of the bone as possible, and then primary reconstruction of the skull and facial skeleton defects is carried out. A few months later, reconstructive surgery is performed.

Possible causes of craniofacial injury include road accidents (51.3\%), blows to the head or face (31.8\%), penetrating skull, orbital or brain injuries (10.4\%), falls from height $(5.4 \%)$, and other causes (1.1\%) [3]. Craniofacial injury makes up 6-9\% of all traumatic brain injuries (TBI) and amounts to 34-52.9\% among all concomitant injuries. Moderate and severe brain injuries are reported in $7 \%$ patients with facial trauma $[4,5]$. Injuries to the central part of the face can be disfiguring. Basilar fractures of the skull involving the frontal sinus, ethmoid labyrinth and sphenoid sinus are a common cause of cerebrospinal fluid (CSF) leaks. Fractures at the interface between the posterior table of the frontal sinus and the lamina cribosa pose a risk for CSF fistulas, which require surgical management [5]. 
Below we describe how one surgical intervention can solve a number of important tasks and report the use of CAD-CAM technology in revision surgery for cranio-orbital traumatic injury $[6,7]$.

\section{Clinical case}

Female patient $U$ aged 32 years presented with posttraumatic CSF rhinorrhea. 5 months ago after the accident, the patient had been transported to the City Hospital and diagnosed with an open penetrating TBI, severe brain contusion, comminuted depressed penetrating fracture of the frontal bone, contusion of bilateral frontal lobes, and displaced fracture of the right zygomatic bone.

Following the accident, the patient's wound was debrided, broken fragments of the posterior frontal sinus wall and the frontal bone were removed, osteosynthesis of the affected zygomatic bone was performed (Fig. 1, 2). Two weeks later, the patient underwent cranioplasty: the frontal bone defect was repaired, the frontal sinus was cranialized and the skull base was reconstructed. Postoperatively, the patient developed CSF rhinorrhea. Lumbar puncture and lumbar drain placement produced no positive effect.

The cosmetic effect of the initial surgery was satisfactory. However, due to the complex geometry of the lost bone fragment, the sustained defect was noticeable (Fig. 3) and the patient had to change her hairstyle to conceal it. Generally, to achieve good outcomes, frontal bone reconstruction should be done with custom-made implants or the plate should be thoroughly modelled.

We were faced with 2 main challenges: perform cranial base plasty and frontal sinuplasty to stop the CSF leak and restore the geometry of the patient's skull.

To identify the source of the CSF leak, CT cisternography was performed (Fig. 4). The scans showed the absence of the posterior frontal sinus wall and the presence of the contrast agent in the frontal sinuses.

A decision was made to repair the anterior cranial fossa to stop the CSF leak, perform frontal bone plasty and install a ventriculoperitoneal shunt during one surgery. The shunt was necessary because the leak had been continuing for 5 months and the risk of damage to the basal cisterns was very high.

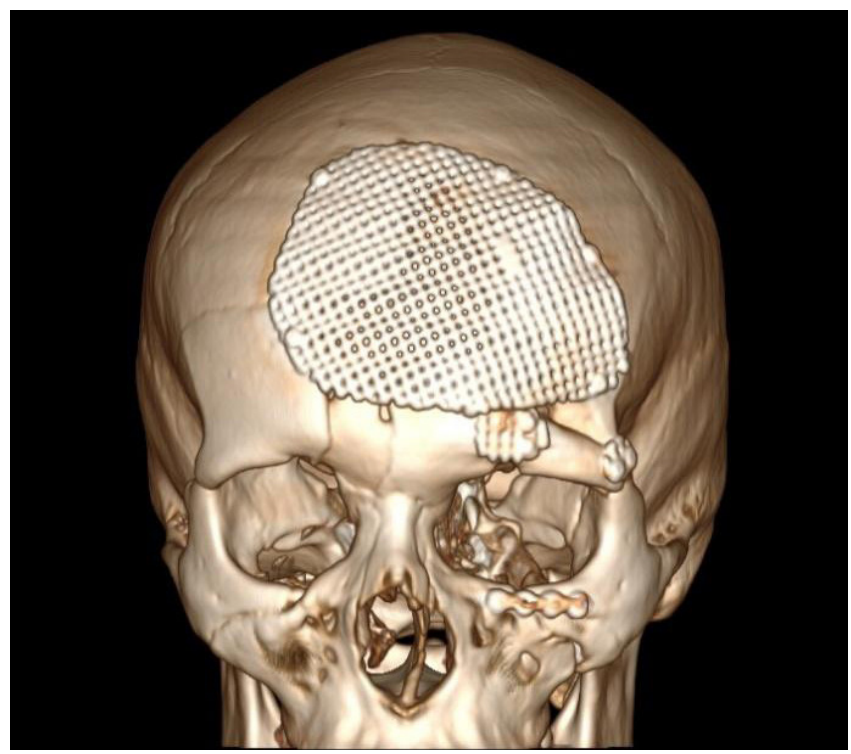

Fig. 1. Computed tomography: 3D skull reconstruction, frontal view. A titanium mesh is visualized in the projection of the frontal bone defect. The image shows frontal lobe fragments forming the superior orbital wall after osteosynthesis

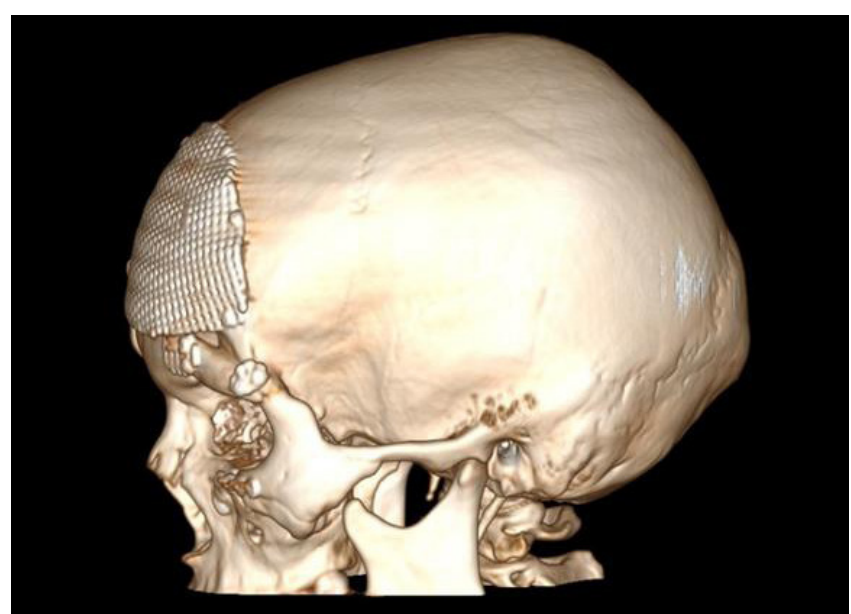

Fig. 2. Computed tomography: 3D skull reconstruction (side view)

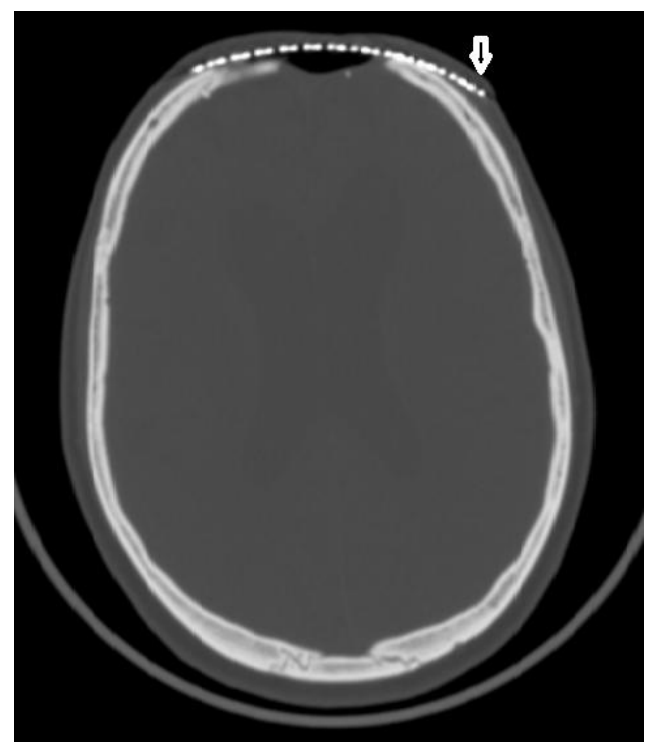

Fig. 3. An axial CT image. The arrow points to the edge of the plate that deforms the cranial contour. The image shows the difference in geometry between the cranial vault and the implant

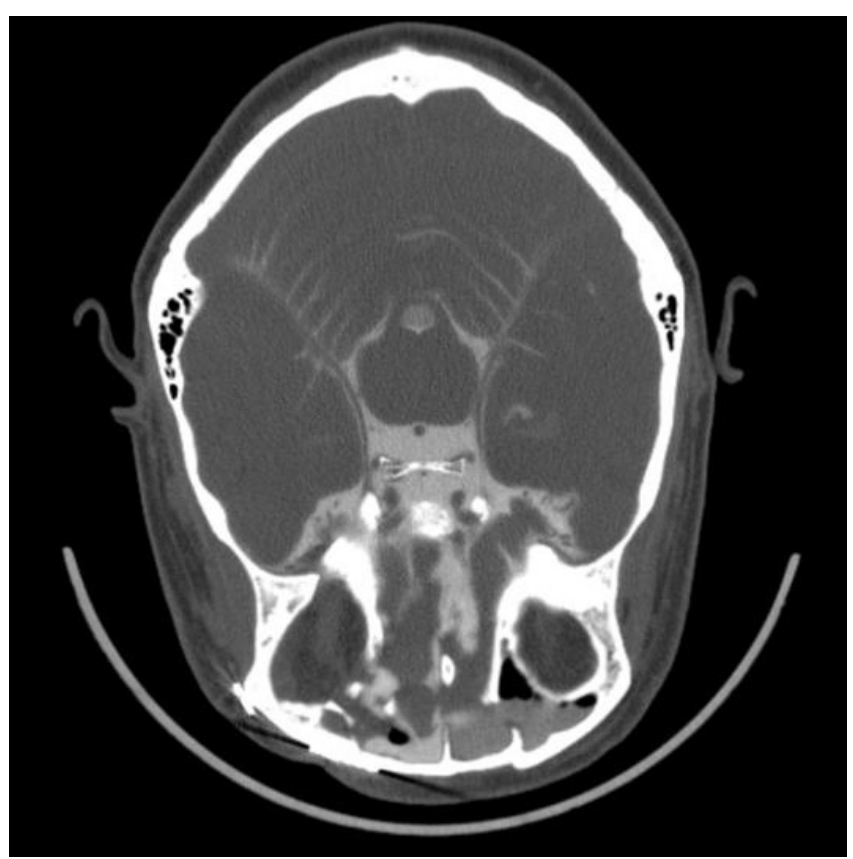

Fig. 4. An axial CT cisternography image 
The implant was designed by Logeeks Medical Systems. Since the defect was already closed with a titanium mesh, there was a need for non-standard design tools, which made the task even more complicated. Using the CAD software, the mesh was visually "removed": normally, a defect has to be open to perform the planning step. The implant was printed from a VT6 alloy (vanadium + titanium + aluminum) on a 3D EOS M 290 printer (EOS GmbH; Germany) using direct metal laser sintering (DMLS). Fig. 1, 4 show multiple lines of displaced fractures (one bone width displacement). Mesh fragments used for osteosynthesis of the superior orbital wall were preserved during the surgery. Prior to the intervention, the patient underwent lumbar puncture and her CSF was collected for analysis. The test revealed no signs of meningitis. Figure 5 and 6 demonstrate stages of the design process in CAD. CAD allowed us to accurately recover the geometry of the skull.

In June 2019, the patient received extradural repair of the skull base with an autologous musculoaponeurotic graft; the donor site was the quadriceps femoris muscle with a fragment of broad fascia and subcutaneous adipose tissue. The complex defect of the frontal bone was closed with the 3D implant. The dural defect was closed with a fibrin-coated thrombin-containing collagen sponge. As an alternative to the external ventricular drain, a lumboperitoneal shunt was installed to reduce intracranial pressure in the postoperative period. The shunt was introduced at the L3-L4 level using a 16-gauge Tuohy needle, passed under the skin and brought to the surface $1.5 \mathrm{~cm}$ below the umbilicus. Then, the shunt was placed into the peritoneum through a paracentesis trocar port.

The implant was installed at the defect site and then adjusted. Due to multiple linear displaced fractures, the patient had developed calluses, which were removed with a high-speed rotating diamond cutter. The implant was fixed with self-tapping screws.

Postoperatively, the patient's condition was satisfactory. A follow-up CT scan was performed (Fig. 7). On day 3, she started complaining of dripping in the throat. Nose blowing caused a headache. Another brain CT scan was ordered.

The scan revealed the presence of pneumocephalus (Fig. 8; red arrow). Revision surgery (repeated reconstruction of the anterior cranial fossa) was performed 5 days after the first intervention. During the surgery, a sandwich technique was used which consisted in multilayered closure of the anterior cranial fossa defect using a musculofascial autologous flap, a synthetic dural substitute and a fibrin-thrombin sponge.

After the intervention, the patient was stable although she had moderate headaches. Her condition was gradually

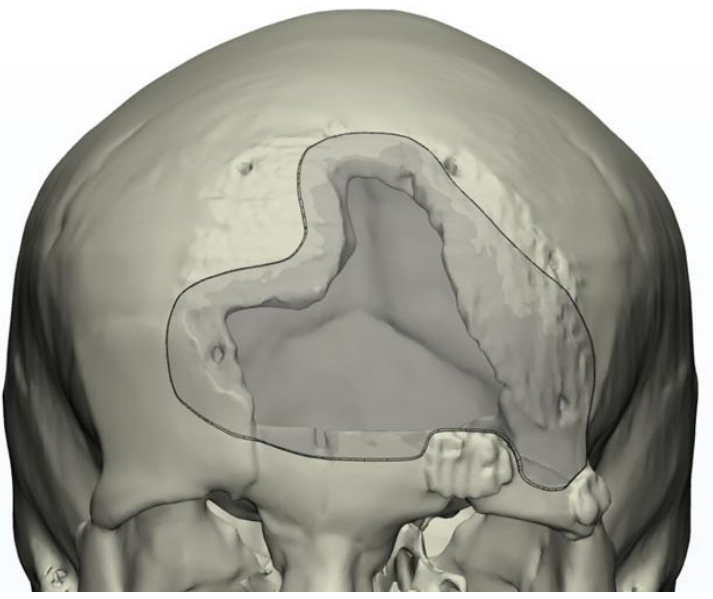

Fig. 5. 3D reconstruction of the skull: CAD planning. The implant is larger than the defect size, which is necessary for more accurate restoration of the frontal bone shape at the planning stage

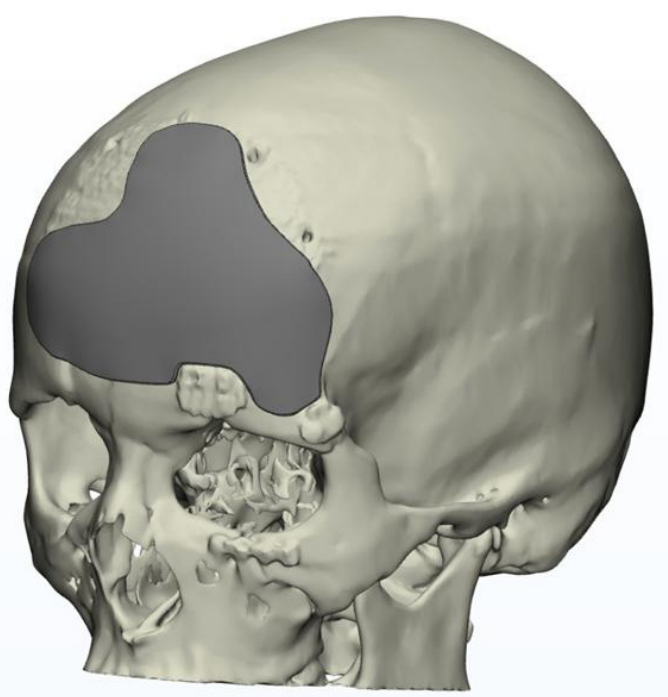

Fig. 6. 3D reconstruction of the skull, CAD planning. The final version of the implant

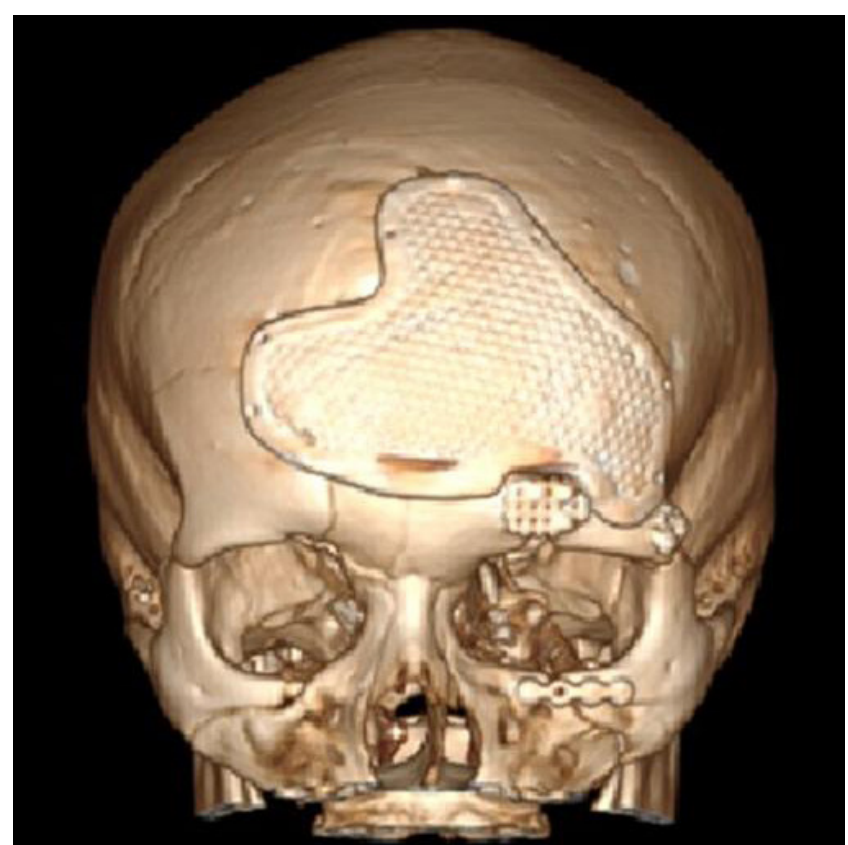

Fig. 7. 3D reconstruction of the skull after the surgery (frontal view)

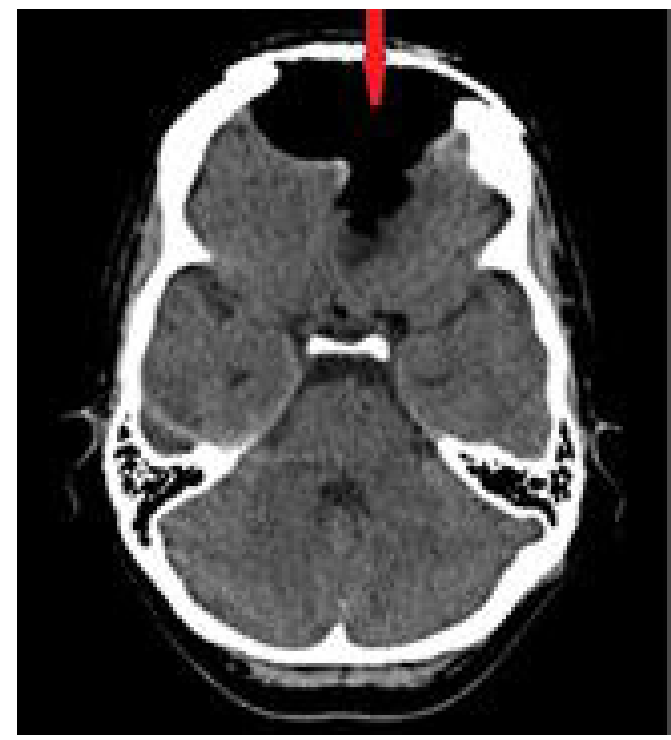

Fig. 8. The axial CT image after the surgical intervention 
improving, the surgical wound was healing by first intention, the cosmetic effect was excellent. There were signs of intracranial hypotension (headaches, vertical dizziness). The shunt was removed 2 weeks after the intervention.

The follow-up CT scan performed after shunt removal demonstrated that the amount of gas had significantly decreased (Fig. 9). On discharge, the patient's condition was satisfactory. So far, CSF leak has not recurred.

\section{DISCUSSION}

CSF leaks after neurosurgery are reported in $0.9-42 \%$ of cases [8]; the risk is determined by a number of factors, including the surgical site, the surgical technique, the patient's general health (compromised immunity, therapy with corticosteroids, uncontrolled diabetes, renal failure, hepatic failure, etc.) In patients with basilar injuries, CSF leaks are hard to control with conservative therapy like lumbar drains; the condition can cause serious complications and increase the risk of death [9]. Repair of skull base defects is required to seal the subdural space and isolate it from the nasal cavity and paranasal sinuses to prevent such complications as pneumocephalus, meningocele, encephalocele, meningitis, meningoencephalitis [10].

The applied repair strategy depends on the location, size, shape of the defect, and proximity of the subarachnoid cisterns [10]. Autologous grafts should be preferred because they do not cause a biological reaction $[9,11]$.

When planning the surgical intervention, it is important to know whether CSF leak pressure is high or low [10, 12]. A lumbar drain or a shunt is placed only if CSF leak pressure is high. As a rule, lumbar drains are placed for 3-5 days. The rate of complications in patients with external lumbar drains can be as high as $12.5 \%$ [9]; the complications include infection, headaches, nerve root irritation, pneumocephalus in the presence of hyperdrainage, etc. During the initial surgery, we used a musculoaponeurotic autologous flap, subcutaneous fat and a fibrin-thrombin sponge [13]. Some authors point to the efficacy of fibrin sealants as a cranioplasty material [14]. In our case, no allografts were used. Multilayer cranioplasty should be a preferred technique in patients at high risk of postoperative CSF leaks [15]. Comminuted frontal bone fractures involving the anterior cranial fossa affect the basal cisternae, so we decided to place a lumboperitoneal shunt. We did not use fibrin glue because multilayer cranioplasty with autologous grafts and a fibrin-thrombin sponge ensure that the defect of the skull base is reliably sealed $[13,14]$. Some authors think that thrombinfibrin sealants do not affect the outcome but simplify the applied surgical technique [16]. After the first intervention, the patient was recommended to temporarily refrain from blowing her nose. Poor adherence led to tension pneumocephalus. During the subsequent revision surgery, the multilayer cranioplasty

\section{References}

1. Aciduman A, Belen D. The earliest document regarding the history of cranioplasty from the ottoman era. Surg Neurol. 2007; 68 (3): 349-53.

2. Sanan A, Haines S. Repairing holes in the head: a history of cranioplasty. Neurosurgery. 1997; 3 (40): 588-603.

3. Shah AM, Jung H, Skirboll S. Materials used in cranioplasty: A history and analysis. Neurosurg Focus. 2014; 36 (4): 19

4. Travma nazo-jetmoidal'nogo kompleksa: nejrohirurgicheskie jesteticheskie aspekty problemy. Jakovenko I. V. i dr. Nejrohirurgija. 2013; 4: 33-38. technique was applied: we used a musculoaponeurotic autologous graft with subcutaneous fat, an allograft (synthetic dural substitute) and fibrin glue. No recurrent CSF leaks were observed in the follow-up period.

\section{CONCLUSION}

It is always preferable to perform a few procedures during one surgery since it can reduce the length of treatment and the level of stress. However, the reported clinical case shows that simultaneous surgeries are not always justifiable despite their advantages. A persistent preoperative CSF leak and conventional therapy failure indicate a possible risk of leak recurrence in the postoperative period. With recurred CSF leaks, operative time for revision surgery is increased because the implant has to be removed first. Besides, there is an increased risk of meningitis and meningoencephalitis due to the presence of a foreign body (an implant) in the setting of persistent CSF leak. Therefore, it is important to consider the duration of the leak, the type of CSF leak pressure (high or low), the tried treatment options, and the outcomes. If external drains do not produce any positive effect and the leak is continuing for over 2 months, the surgical treatment should be split in 2 phases. First, the skull base should be repaired and then (2 months later) the frontal bone defect can be finally closed. Although the resulting cosmetic effect may not be satisfactory, this approach is safer. It is still debatable whether lumbar puncture and shunting should be used as auxiliary techniques for reducing intracranial pressure.

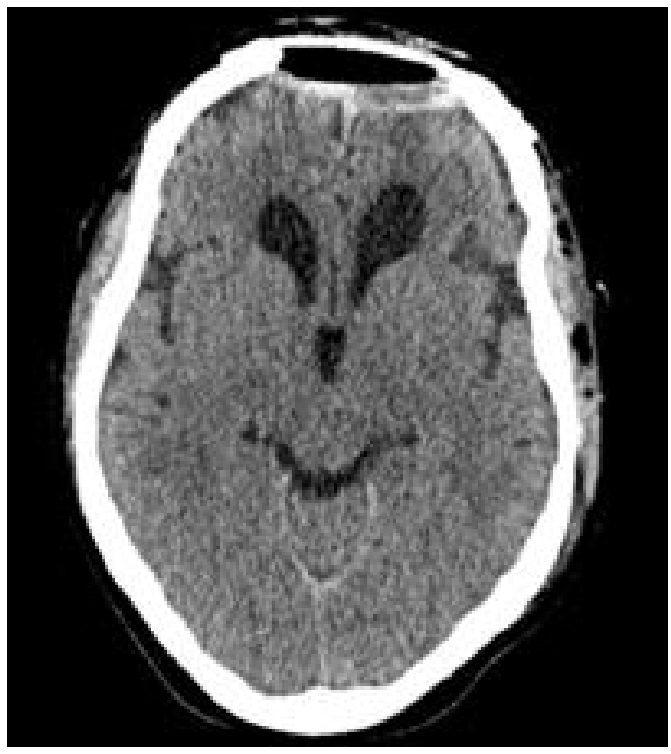

Fig. 9. Postoperative follow-up CT images 
experience and review of the literature. Surg Neurol Int. 2016; 7 S463-8. Available from: http://surgicalneurologyint.com/Duralrepair-using-autologous-fat:-Our-experience-and-review-of-theliterature//.

8. Eolchijan SA, Potapov AA, Serova NK, Kataev MG, Sergeeva LA, Zaharova NE, i dr. Rekonstruktivnaja hirurgija kranioorbital'nyh povrezhdenij. Zhurnal «Voprosy nejrohirurgii» imeni N. N. Burdenko. 2011; 75 (2): 25-40. Russian.

9. Naik AN, Lancione PJ, Parikh AS, Lin C, Silverman DA, Carrau RL, VanKoevering KK, Seim NB, Old MO, Kang SY. Anterior skull base reconstruction: a contemporary review. Plast Aesthet Res 2021; 8: 22. Available from: http://dx.doi.org/10.20517/23479264.2021 .05

10. Krishnan SS, Manuel A, Vasudevan MC. Delayed pneumoventricle following endonasal cerebrospinal fluid rhinorrhea repair with thecoperitoneal shunt. Asian J Neurosurg. 2019; 14: 325-8.

11. Krjukov Al, Turovskij AB, Godkov IM, Kudrjavceva YuS. Lechenie rinolikvorei posle travm osnovanija cherepa. Rossijskaja rinologija. 2011; 19 (2): 54-55. Russian.

12. Shimanskij VN, Poshataev VK, Odamanov DA, Shevchenko KV Metodika primenenija materiala TahoKomb dlja plastiki tverdoj

\section{Литература}

1. Aciduman A, Belen D. The earliest document regarding the history of cranioplasty from the ottoman era. Surg Neurol. 2007; 68 (3): 349-53.

2. Sanan A, Haines S. Repairing holes in the head: a history of cranioplasty. Neurosurgery. 1997; 3 (40): 588-603.

3. Shah AM, Jung H, Skirboll S. Materials used in cranioplasty: A history and analysis. Neurosurg Focus. 2014; 36 (4): 19.

4. Травма назо-этмоидального комплекса: нейрохирургические и эстетические аспекты проблемы. Яковенко И. В. и др. Нейрохирургия. 2013; 4: 33-38.

5. Чобулов С. А., Кравчук А. Д., Потапов А.А., Лихтерман Л. Б. Маряхин А. Д., Синбухова Е. В. Современные аспекты реконструктивной хирургии десектов черепа. Журнал «Вопросы нейрохирургии» имени Н. Н. Бурденко. 2019; 83 (2): 115-24.

6. Гольбин Д. А., Миндлин С. Н. Тактика пластического закрытия базальных десектов после удаления срединных новообразований передних отделов основания черепа. Журнал «Вопросы нейрохирургии» имени Н.Н. Бурденко. 2017: 81 (3): 77-87.

7. Di Vitantonio H, De Paulis D, Del Maestro M, Ricci A, Dechord SR, Marzi S, et al. Dural repair using autologous fat: Our experience and review of the literature. Surg Neurol Int. 2016 7: S463-8. Available from: http://surgicalneurologyint.com/Duralrepair-using-autologous-fat:-Our-experience-and-review-of-theliterature//.

8. Еолчиян С. А., Потапов А. А., Серова Н. К., Катаев М. Г., Сергеева Л. А., Захарова Н. Е., и др. Реконструктивная хирургия краниоорбитальных повреждений. Журнал «Вопросы нейрохирургии» имени Н. Н. Бурденко. 2011; 75 (2): $25-40$.

9. Naik AN, Lancione PJ, Parikh AS, Lin C, Silverman DA, Carrau RL, VanKoevering KK, Seim NB, Old MO, Kang SY. Anterior skull 